\title{
Proteomic analysis of purified turkey adenovirus 3 virions
}

\author{
Pankaj Kumar ${ }^{1}$, Jan van den Hurk', Lisanework E. Ayalew ${ }^{1}$, Amit Gaba ${ }^{1}$ and Suresh K. Tikoo ${ }^{1,2^{*}}$
}

\begin{abstract}
Turkey adenovirus 3 (TAdV-3) causes high mortality and significant economic losses to the turkey industry. However, little is known about the molecular determinants required for viral replication and pathogenesis. Moreover, TAdV-3 does not grow well in cell culture, thus detailed structural studies of the infectious particle is particularly challenging. To develop a better understanding of virus-host interactions, we performed a comprehensive proteomic analysis of proteinase $\mathrm{K}$ treated purified TAdV-3 virions isolated from spleens of infected turkeys, by utilizing one-dimensional liquid chromatography mass spectrometry. Our analysis resulted in the identification of 13 viral proteins associated with TAdV-3 virions including a novel uncharacterized TaV3gp04 protein. Further, we detected 18 host proteins in purified virions, many of which are involved in cell-to cell spread, cytoskeleton dynamics and virus replication. Notably, seven of these host proteins have not yet been reported to be present in any other purified virus. In addition, five of these proteins are known antiviral host restriction factors. The availability of reagents allowed us to identify two cellular proteins (collagen alpha-1 (VI) chain and haemoglobin) in the purified TAdV-3 preparations. These results represent the first comprehensive proteomic profile of TAdV-3 and may provide information for illustrating TAdV-3 replication and pathogenesis.
\end{abstract}

\section{Introduction}

Hemorrhagic enteritis (HE) is an economically important disease of turkeys characterized by depression, splenic enlargement, intestinal haemorrhages and sudden death [1]. The disease is caused by turkey adenovirus 3 (TAdV-3), also known as hemorrhagic enteritis virus (HEV), a member of genus Siadenovirus $A$ [2]. Oral infection of susceptible turkeys with pathogenic TAdV-3 strains results in well-characterized splenomegaly and intestinal bleeding in 4 to 6 days causing subclinical infections and mortality [3]. Although TAdV-3 remains one of the most important causes of economic loss to turkey industry, critical molecular determinants of virulence and factors affecting virus replication are not well understood. This may be in part because of unavailability of an efficient "in vitro" tissue culture system for propagation of TAdV-3 [4-6].

The genome of TAdV-3 is 26,263 bp [7]. Although, TAdV-3 genomic organization of central block of

\footnotetext{
* Correspondence: Suresh.tik@usask.ca

${ }^{1}$ Vaccine and Infectious Disease Organization -International Vaccine Center (VIDO- InterVac1), University of Saskatchewan, Saskatoon S7N 5E3, SK, Canada ${ }^{2}$ Vaccinology \& Immunotherapeutics program, School of Public Health, University of Saskatchewan, Saskatoon S7N 5E5, SK, Canada
}

genus-common genes [8] appears similar to that of other adenovirus genomes [7], the left (E1) and right (E4) terminal regions appear absent. Interestingly, TAdV-3 encodes a genus specific protein, which shows similarity to bacterial sialidase protein [8]. Although Western blot analysis of purified TAdV-3 particles isolated from crude spleen extract revealed presence of eleven structural polypeptides with apparent molecular weight ranging from 9.5 to $96 \mathrm{kDa}$ [9], no systematic study has been performed to identify the precise protein composition of purified TAdV-3 particles.

In recent years, mass spectrometry (MS) based proteomic characterization has revealed important insights into viral replication, tropism and virulence for a number of different enveloped viruses [10-14]. In contrast, a few proteomic studies have been reported for nonenveloped viruses [15-18]. Additionally, there is now compelling evidence suggesting that host cellular proteins incorporated in the virions play an important role in viral replication and pathogenesis $[10,13,19,20]$. Using MS based approaches, a number of host proteins have been reported to be incorporated into RNA viruses ("human immunodeficiency virus-1 [10,13]"; "simian immunodeficiency virus [21]"; "respiratory syncytial virus 
[22]; hepatitis C virus [23]"; "swine hepatitis E virus [24]"; "coronavirus [25]" and "influenza [20,26]") or DNA viruses ("herpes simplex virus 1 [27]"; "African swine fever virus [28]"; "KSHV [29]"; "Marek's disease virus (MDV) [30]”, and "mimivirus [31]"). However, to the best of our knowledge, characterization of the host cellular factors integrated into virions for any member of Adenoviridae family including TAdV-3 has not been reported so far.

Here, we report the protein composition of the purified TAdV-3 particles by performing a comprehensive proteomic analysis utilizing liquid chromatography-mass spectrometry (LC-MS/ MS). Our analysis resulted in successful identification of 13 viral structural proteins and 18 host-incorporated proteins. Moreover, incorporation of two host proteins in purified virions was verified by Western blot analysis using available immunological reagents.

\section{Materials and methods}

\section{Turkey and viruses}

All turkey procedures were approved by University Committee of Animal Care and Supply (protocol \# 19940211) at the University of Saskatchewan, Saskatoon, Canada according to guidelines set by the Canadian Council of Animal Care.

Day-old Hybrid poults obtained from Chinook belt Hatcheries, Calgary, Canada were housed in isolation rooms throughout the experiments. The avirulent TAdV-3 isolate (pheasant origin) was passaged in sero negative turkeys by oral inoculation and purified from crude spleen extracts, as described earlier [32].

\section{Virion purification}

The TAdV-3 virions were purified as previously described [9]. The proteinase $\mathrm{K}(\mathrm{pK})$ treatment of purified TAdV-3 virions was performed as described previously [33]. Briefly, double CsCl-purified virions were incubated in $1 \mathrm{~mL}$ of MNT buffer (30 mM morpholineethanesulfonic acid [MES], $10 \mathrm{mM} \mathrm{NaCl}$, and $20 \mathrm{mM}$ Tris- $\mathrm{HCl}$ [pH 7.4]) containing proteinase $\mathrm{K}$ [0 to $20 \mu \mathrm{g}]$ (Roche, Mannheim, Germany) for $45 \mathrm{~min}$ at room temperature and subsequently treated with " $2 \mathrm{mM}$ phenylmethylsulfonyl fluoride" (Roche) prior to purification by $\mathrm{CsCl}$ density gradient centrifugation. Purified virions were resuspended in $10 \%$ glycerol and stored at $-80{ }^{\circ} \mathrm{C}$ until further use. The experiments were performed in triplicate employing three independent virus preparations.

\section{Negative staining and transmission electron microscopy}

Electron microscopy was performed on $\mathrm{CsCl}_{2}$ gradient purified TAdV-3 virions (proteinase $\mathrm{K}$ treated or untreated) at EM facility at Biology department, University of Victoria, BC, Canada, as described [34]. Briefly, for negatively stained preparation, $\mathrm{CsCl}_{2}$ gradient purified virus was first applied onto carbon and formvar coated grids, washed with $\mathrm{H}_{2} \mathrm{O}$ and stained with $2 \%$ aqueous phosphotungstic acid. The specimens were photographed using a charge-coupled device camera (Advanced Microscopy Techniques, AMT CCD camera equipped Hitachi H7000 TEM operating at $75 \mathrm{kv}$ ).

\section{Antibodies}

Production and characterization of anti-TAdV-3 serum and monoclonal antibodies (MAbs) recognizing TAdV-3 hexon (15G4) and fiber (87-03) proteins has been described earlier $[4,9]$. Chicken polyclonal anti-human hemoglobin serum (ab28961) was purchased from Abcam (Cambridge, MA, USA). Rabbit polyclonal antihuman collagen type VI alpha-1 serum (COL6A1) was purchased from antibodies-online Inc. (Atlanta, GA, USA). Alkaline phosphatase conjugated goat anti-rabbit (Sigma Aldrich) and peroxidase-conjugated goat "antiturkey" IgG (KPL, Maryland, USA) were used as described $[4,9]$.

\section{Western blotting}

Proteins from purified TAdV-3 were separated by sodium dodecyl sulphate (SDS) polyacrylamide gel electrophoresis (PAGE) on $10-15 \%$ or $4-15 \%$ precast gradient gels (Bio-Rad),transferred to nitrocellulose membrane and probed with protein specific antibodies as described previously [9].

\section{In solution trypsin digestion}

Proteins from $\mathrm{CsCl}_{2}$ gradient purified virion-enriched (proteinase $\mathrm{K}$ treated or untreated) samples were diluted with $200 \mathrm{mM}$ ammonium bicarbonate prior to reduction with $200 \mathrm{mM}$ dithiothreitol and incubated $30 \mathrm{~min}$ at $37{ }^{\circ} \mathrm{C}$. Cysteine sulfhydryl groups were alkylated with $20 \mu \mathrm{L}$ of $100 \mathrm{mM}$ iodoacetamide $\left(30 \mathrm{~min}\right.$ at $37{ }^{\circ} \mathrm{C}$ in darkness). Each sample was digested with $5 \mu \mathrm{g}$ of trypsin (Promega) at $37{ }^{\circ} \mathrm{C}$ for $16 \mathrm{~h}[33,35]$. Finally, the samples were de-salted on a Waters HLB Oasis column, speed vac concentrated and stored at $-80{ }^{\circ} \mathrm{C}$ prior to LC-MS analysis.

\section{LC-MS/MS analysis}

The peptide mixtures were separated by on-line reverse phase chromatography using a EASY-nLC II system (Thermo Scientific) with a reversed-phase Magic C18AQ pre-column (100 $\mu \mathrm{m}$ I.D., $2 \mathrm{~cm}$ length, $5 \mu \mathrm{m}$, $100 \AA$ A , Michrom Bio Resources Inc, Auburn, CA, USA) and reversed phase nano-analytical column Magic C-

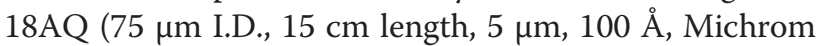
Bio Resources Inc, Auburn, CA, USA) at a flow rate of $3001 / \mathrm{min}$. The resulting peptides were analyzed by the chromatography system, which was coupled on-line with a LTQ OrbitrapVelos mass spectrometer (Thermo Fisher 
Scientific, Bremen, Germany) equipped with a NanosprayFlex source (Thermo Fisher Scientific) as described previously $[33,35]$. The data was acquired with keratin and trypsin peptide mass exclusion lists.

\section{MS/MS data analysis}

Raw files were analysed with Proteome Discoverer 1.4 software suite (Thermo Scientific). Parameters for the spectrum selection to generate peak lists of the collisioninduced "dissociation (CID) spectra were activation type: CID"; (s/n cut-off: 1.5; total intensity threshold: 0; minimum peak count: 1 ; precursor mass: $350-5000 \mathrm{Da}$ ). The peak lists were submitted to an in-house Mascot 2.3 server against "the following databases": Uniprot_Trembl 20111103 (17 651715 sequences; 5,747,683, 275 residues) and Uniprot-Swissprot 20110104 (523 151 sequences; 184 678199 residues) all species taxonomy.

Database search parameters were as follows: precursor tolerance $8 \mathrm{ppm}$; MS/MS tolerance $0.6 \mathrm{Da}$; Trypsin enzyme 1 missed cleavages; Fourier Transform Ion Cyclotron Resonance (FT-ICR) instrument type; fixed modification: carbamidomethylation $(\mathrm{C})$; variable modifications: deamidation (N,Q); oxidation (M). The Decoy database Percolator settings: Max delta Cn 0.05; Target FDR strict 0.01 , Target FDR relaxed 0.05 with validation based on q-Value. Additional virus only species searches were also performed with tolerances previously mentioned. All data were also searched against NCBI (Gallus gallus (chicken)) database to detect viral and host proteins. Only sequences identified with a mascot score value greater than 30 were considered as significant. Protein identifications were accepted when the peptide probability was greater than $95.0 \%[33,35]$, the protein probability greater than $99.0 \%$, and contained at least 2 identified peptides. Peptide identifications were systemically evaluated manually.

\section{Results}

Purification of TAdV-3 virions

Due to difficulty in propagating turkey adenovirus 3 in cell culture system, TAdV-3 was propagated in six to 8 week old turkeys. TAdV-3 virions were purified from spleens of

(A)

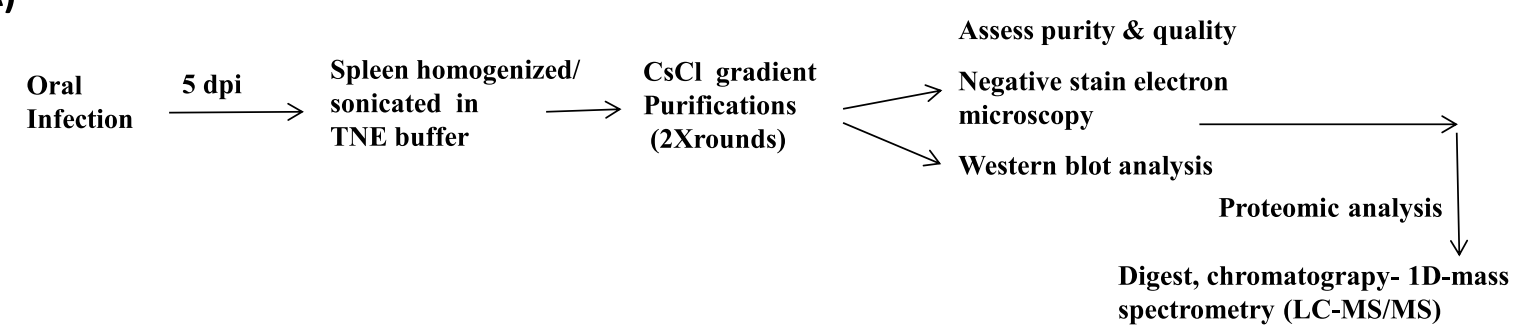

(B)

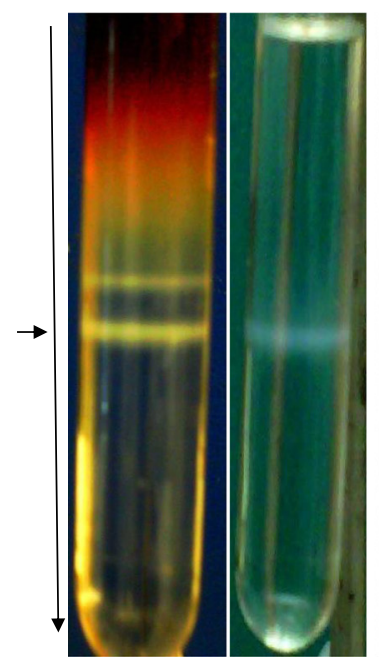

(C)

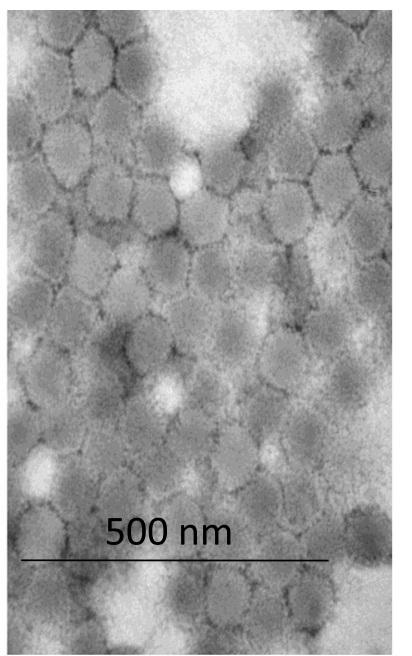

(D)

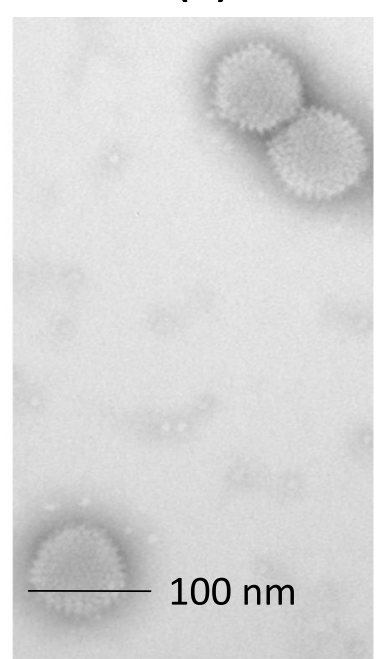

(E)

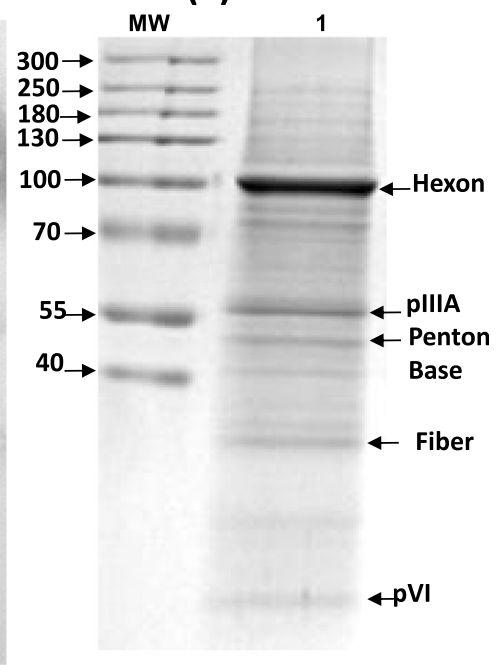

Figure 1 Purification of TAdV-3 virions. A Strategy for enrichment and purification of TAdV-3 virions. Flow diagram depicts the strategy. B CsCl2 purification of TAdV-3. The lower band containing mature viruses (left panel) subjected to second round of CsCl (right panel). C-E Analysis of TAdV-3 virions purity. Electron micrograph of CsCl purified TAdV-3 negatively stained with $2 \%$ aqueous phosphotungstic acid (Direct magnification $100000 X)$ (C) and (direct magnification 150000X) (D). E Analysis of TAdV-3 polypeptides. Purified TAdV-3 proteins were separated by 10-15\% SDS-PAGE and analyzed by Western blot using turkey anti-TAdV-3 serum [4,9] and peroxidase-linked goat anti-turkey lgG antibodies (right panel). The identified polypeptides (lane 1) are depicted. Molecular weight markers (MW) in kDa are shown on the left of the panel. 
turkeys inoculated orally with an avirulent vaccine strain of TAdV-3 [4,9] (Figure 1A). Following $\mathrm{CsCl}_{2}$ density gradient purification, two distinct bands were observed, the upper band (present at lower density) containing capsid and the lower band (at higher density, between 1.25 and 1.35) containing complete infectious viruses (Figure 1B, left panel). The lower band was subjected to second round of $\mathrm{CsCl}_{2}$ density gradient purification resulting in single band containing purified virions (Figure 1B, right panel). Virion-enriched preparations were checked for quality by negative stain transmission electron microscopy (TEM) (Figures $1 \mathrm{C}$ and D). As seen, virions demonstrated uniform, intact TAdV-3 virus particles of $100 \mathrm{~nm}$ diameter. These TEM results were consistent with the quality and apparent purity reported earlier [33,35]. The purity of the virion preparation was also determined by Western blot analysis using turkey anti-TAdV-3 sera. As seen in Figure 1E, polypeptides of $96 \mathrm{~K}$ (hexon), $57 \mathrm{~K}$ (IIIa), $52 \mathrm{~K}$ (penton base), $29 \mathrm{~K}$ (fiber) and $24 \mathrm{~K}$ (pVI) were detected in $\mathrm{CsCl}_{2}$ purified TAdV-3 virions. These findings suggest that our enrichment procedure yielded a highly purified preparation of TAdV-3 virions.

\section{Protein composition of $\mathrm{CsCl}_{2}$ purified TAdV-3 virions}

The protein composition of TAdV-3 virions was analyzed by the method of in-solution trypsin "digestion a gel-free approach" to MS that subject the entire sample

Table 1 TAdV-3 proteins identified by LC-MS/MS

\begin{tabular}{|c|c|c|c|c|}
\hline \multirow[b]{2}{*}{$\begin{array}{l}\text { Protein } \\
\text { name }\end{array}$} & \multicolumn{4}{|c|}{ LC-MS/MS } \\
\hline & $\begin{array}{l}\mathrm{MW} \\
(\mathrm{kDa})^{\mathrm{a}}\end{array}$ & $\begin{array}{l}\text { No. of } \\
\text { peptides }\end{array}$ & $\begin{array}{l}\text { Mascot } \\
\text { score }^{b}\end{array}$ & $\begin{array}{l}\text { Sequence } \\
\text { coverage (\%) }\end{array}$ \\
\hline$\overline{p V l}$ & 24.98 & 146 & 4378 & 69 \\
\hline pllIA & 57.52 & 59 & 2377 & 96 \\
\hline$p V I I$ & 13.20 & 163 & 1984 & 91 \\
\hline IVa2 & 42.36 & 39 & 1046 & 48 \\
\hline Penton Base & 34.17 & 46 & 857 & 54 \\
\hline Hexon & 101.65 & 42 & 659 & 23 \\
\hline $\mathrm{pVIII}$ & 21.75 & 35 & 655 & 81 \\
\hline Fiber & 29.13 & 18 & 620 & 29 \\
\hline $\begin{array}{l}\text { Hypothetical } \\
\text { Protein } \\
\text { (TaV3gp04) }\end{array}$ & 13.32 & 17 & 452 & 35 \\
\hline DBP & 44.21 & 13 & 389 & 12 \\
\hline Sialidase & 64.9 & 9 & 162 & 6 \\
\hline $\mathrm{pX}$ & 6.15 & 9 & 137 & 29 \\
\hline Adenain & 25.33 & 9 & 113 & 18 \\
\hline pTP & 70.72 & 7 & 102 & 9 \\
\hline $22 \mathrm{~K}$ & 10.51 & 5 & 42 & 29 \\
\hline
\end{tabular}

A novel virion-associated viral protein is shown in bold black.

${ }^{\text {a }}$ Theoritical molecular mass.

${ }^{\mathrm{b}} \mathrm{A}$ Mascot score $\geq 35$ is significant $(p<0.05)$.

'Sequence coverage is based on peptides with an unique sequence. to sequential one-dimensional reversed-phase chromatography coupled on-line to MS/MS analysis (1D-nanospray-LC-MS/MS). This method eliminates the problems reported with proteins that either enter gel poorly or extracted inefficiently from the gel slices. Our LC-MS/MS analysis revealed a total of 15 virus-encoded proteins packaged in the purified TAdV-3 virions. This included 13 proteins, which have been detected in human adenovirus 5 (HAdV-5) virions [16] (Table 1), a novel

Table 2 Cellular proteins associated with purified TAdV-3 virions identified by LC-MS/MS

\begin{tabular}{|c|c|c|c|c|}
\hline \multirow[b]{2}{*}{ Protein name } & \multicolumn{4}{|c|}{ LC-MS/MS } \\
\hline & $\begin{array}{l}\text { MW } \\
(\mathbf{k D a})^{\mathrm{a}}\end{array}$ & $\begin{array}{l}\text { No. of } \\
\text { peptides }\end{array}$ & $\begin{array}{l}\text { Mascot } \\
\text { score }^{b}\end{array}$ & $\begin{array}{l}\text { Sequence } \\
\text { coverage }(\%)^{c}\end{array}$ \\
\hline Actin & 42.36 & 56 & 607 & 38 \\
\hline $\begin{array}{l}\text { TAR DNA binding } \\
\text { protein } 43\end{array}$ & 44.90 & 22 & 656 & 24 \\
\hline Tublin beta5 & 50.28 & 25 & 535 & 21 \\
\hline Tubulin alpha-1A & 50.78 & 19 & 444 & 26 \\
\hline LUC7 like1 & 47.60 & 28 & 482 & 28 \\
\hline Tublin beta3 & 50.09 & 25 & 338 & 20 \\
\hline $\begin{array}{l}\text { High mobility group } \\
\text { protein B1 }\end{array}$ & 23.08 & 13 & 349 & 34 \\
\hline $\begin{array}{l}\text { High mobility group } \\
\text { protein B2 }\end{array}$ & 23.98 & 24 & 227 & 24 \\
\hline $\begin{array}{l}78 \text { kDa glucose- } \\
\text { regulated protein }\end{array}$ & 72.08 & 21 & 135 & 5 \\
\hline Myeloid protein 1 & 36.41 & 14 & 240 & 23 \\
\hline Desmin & 53.30 & 16 & 212 & 11 \\
\hline Cathelicidin-3 & 16.61 & 5 & 146 & 32 \\
\hline Protein PML & 35.99 & 13 & 158 & 18 \\
\hline Vimentin & 53.16 & 16 & 157 & 17 \\
\hline Splicing factor U2AF & 28.19 & 7 & 154 & 20 \\
\hline $\begin{array}{l}\text { Collagen alpha-1 (VI) } \\
\text { chain }\end{array}$ & 110.0 & 5 & 146 & 32 \\
\hline $\begin{array}{l}\text { Elongation factor } 1 \text { - } \\
\text { alpha }\end{array}$ & 49.48 & 6 & 143 & 15 \\
\hline Protein syndesmos & 33.44 & 4 & 140 & 3 \\
\hline Ferritin & 17.13 & 8 & 129 & 22 \\
\hline $\begin{array}{l}\text { Serine/arginine-rich } \\
\text { splicing factor } 5 a\end{array}$ & 27.15 & 2 & 76 & 7 \\
\hline Fibronectin & 276.017 & 3 & 76 & 2 \\
\hline Gallinacin-2 & 7.49 & 2 & 75 & 12 \\
\hline Cathespsin B & 38.47 & 3 & 70 & 9 \\
\hline $\begin{array}{l}\text { Hemoglobinsubunit } \\
\text { beta }\end{array}$ & 16.62 & 6 & 64 & 19 \\
\hline L-amino acid oxidase & 59.08 & 3 & 56 & 3 \\
\hline $\begin{array}{l}\text { Hemoglobin subunit } \\
\text { alpha-A }\end{array}$ & 15.10 & 3 & 42 & 17 \\
\hline
\end{tabular}

aTheoritical molecular mass.

${ }^{\mathrm{b}} \mathrm{A}$ Mascot score $\geq 35$ is significant $(p<0.05)$.

'Sequence coverage is based on peptides with an unique sequence. 
uncharacterized hypothetical viral protein designated as TaV3gp04 (Table 1, Additional file 1) and a non-structural viral protein $(22 \mathrm{~K})$ to be associated with TAdV-3 virions. In addition to TAdV-3 encoded viral proteins, interestingly 26 cellular proteins appeared to be associated with purified TAdV-3 virions (Table 2).

\section{Protein composition of proteinase $\mathrm{K}$ treated $\mathrm{CsCl}$ purified TAdV-3 virions}

To determine if the host proteins are actually incorporated into the virions, the purified $\mathrm{TAdV}-3$ virions were treated with proteinase $\mathrm{K}(20 \mu \mathrm{g} / \mathrm{mL})$ and subjected to another round (third round) of $\mathrm{CsCl}_{2}$ purification. The proteinase $\mathrm{K}$ treated and untreated, purified virions were then analysed by Western blotting. Proteinase $\mathrm{K}$ treatment degrades fiber protein protruding from the capsid but does not degrade hexon protein not protruding from the capsid. As seen in Figure 2A, hexon protein could be detected in proteinase $\mathrm{K}$ treated or untreated TAdV-3 virions. In contrast, fiber protein could only be detected in untreated virions, but not in proteinase $\mathrm{K}$ treated virions. Moreover, TEM analysis suggested that the virions were intact and maintained virion integrity after proteinase $\mathrm{K}$ treatment and $\mathrm{CsCl}_{2}$ density gradient purification (Figure 2B).

The LC-MS/MS analysis of proteinase $\mathrm{K}$ treated $\mathrm{CsCl}_{2}$ density gradient purified TAdV-3 virions identified eleven virus-encoded proteins (hexon, pVI, pVII, penton base, pVIII, sialidase, IIIA, adenain, pX, IVa2 and DBP) previously reported to be in other adenoviruses (Table 3 and Figure 3A) [16]. In addition, a novel viral protein TaV3gp04 remains an integrated part of proteinase $\mathrm{K}$ treated TAdV-3 virions (Table 3, Additional file 1). As expected, peptides representing fiber protein were not detected in proteinase

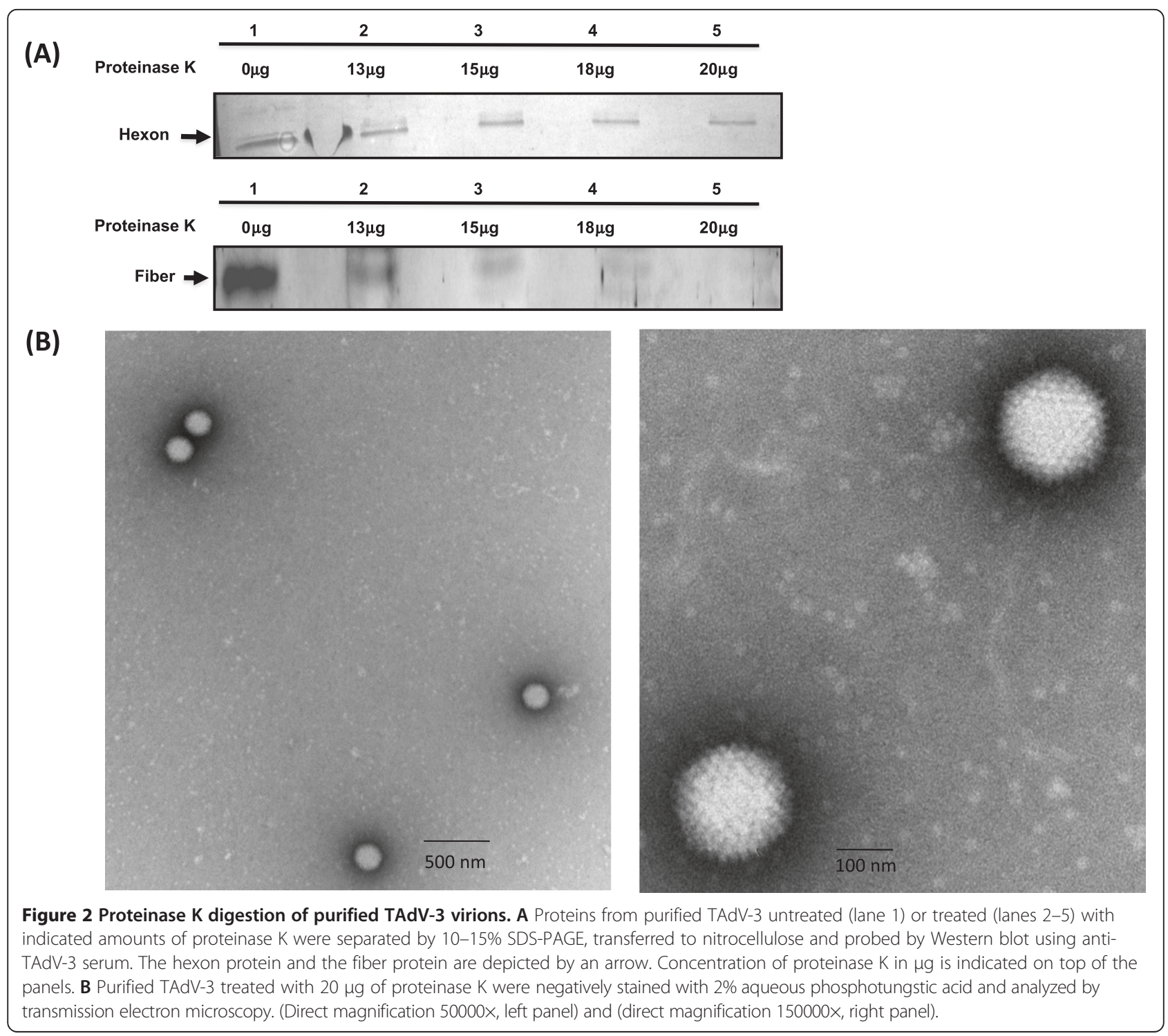




\begin{tabular}{|c|c|c|c|c|c|}
\hline \multirow[b]{2}{*}{$\begin{array}{l}\text { Protein } \\
\text { name }\end{array}$} & \multicolumn{5}{|c|}{ LC-MS/MS } \\
\hline & $\begin{array}{l}\mathrm{MW} \\
(\mathrm{kDa})^{\mathrm{a}}\end{array}$ & $\mathrm{pK}^{\mathrm{b}}$ & $\begin{array}{l}\text { No. of } \\
\text { peptides }\end{array}$ & $\begin{array}{l}\text { Mascot } \\
\text { score }^{c}\end{array}$ & $\begin{array}{l}\text { Sequence } \\
\text { coverage (\%) }\end{array}$ \\
\hline Hexon & 101.653 & + & 71 & 1327 & 37 \\
\hline PVI & 24.989 & + & 15 & 560 & 32 \\
\hline PVII & 13.201 & + & 24 & 467 & 70 \\
\hline $\begin{array}{l}\text { Hypothetical } \\
\text { Protein } \\
\text { (TaV3gp04) }\end{array}$ & 13.32 & + & 10 & 165 & 36 \\
\hline Fiber & - & - & - & - & - \\
\hline Penton Base & 34.179 & + & 13 & 153 & 19 \\
\hline PVIII & 21.75 & + & 8 & 135 & 12 \\
\hline Sialidase & 64.9 & + & 2 & 84 & 10 \\
\hline$\| \mathrm{A}$ & 57.52 & + & 10 & 83 & 10 \\
\hline Adenain & 25.33 & + & 2 & 55 & 6 \\
\hline PX & 6.15 & + & 1 & 39 & 13 \\
\hline IVa2 & 42.36 & + & 2 & 35 & 2 \\
\hline DBP & 44.21 & + & 1 & 24 & 2 \\
\hline pTP & - & - & - & - & - \\
\hline $22 \mathrm{~K}$ & - & - & - & - & - \\
\hline
\end{tabular}

A novel virion-associated viral protein is shown in bold black. ${ }^{a}$ Theoritical molecular mass.

${ }_{\mathrm{bK}}^{\mathrm{p}}$, proteinase $\mathrm{K}$ treatment + .

${ }^{c} A$ Mascot score $\geq 35$ is significant $(p<0.05)$.

${ }^{d}$ Sequence coverage is based on peptides with an unique sequence.

$\mathrm{K}$ treated TAdV-3 virions. In addition, pTP and $22 \mathrm{~K}$ virion proteins were not detected in proteinase $K$ treated TAdV-3 (Table 3). The high mascot scores and number of peptides observed for hexon, pVI and pVII presumably reflect the fact that they are perhaps the most abundant proteins in the TAdV-3 particles.

Interestingly only 18 host proteins were exclusively detected in proteinase $\mathrm{K}$ treated TAdV-3 virions (Table 4 and Figure $3 \mathrm{~B}$ ). Notably, thirteen of these host proteins were the same as detected in the untreated TAdV-3 virions (Table 4, Figure 3B) indicating that these proteins are part of the TAdV-3 virions. Among these proteins, promyelocytic leukemia protein (PML) isoform X6 (Additional file 2), collagen alpha-1(VI) chain (Additional file 3), haemoglobin subunit alpha (Additional file 4) and haemoglobin subunit beta (Additional file 5) appeared abundant. The PML protein appears as abundant as viral structural protein pVIII or penton base peptide. In addition, five host proteins namely, vitronectin, collagen alpha-3 (VI) chain, collagen alpha-2 (VI) chain, tyrosine protein phosphatase and turkey heterophil peptide 2 (THP-2) were only detected in proteinase $\mathrm{K}$ treated TAdV-3 virions.

Functional classification of the identified proteins revealed that many of these proteins participate in a common molecular pathway (Table 4 and Figure $3 \mathrm{C}$ ) and are involved in innate immunity, cell adhesion, cytoskeleton organization and virus replication.

\section{Validation of cellular proteins incorporated into TAdV-3 virions}

Non availability of turkey host protein specific antisera made it difficult to verify the packaging of host proteins in TAdV-3 virions. However, human collagen alpha-1(VI) peptides showed $70 \%$ identity to turkey collagen alpha1(VI) and chicken collagen alpha-1(VI) (Additional file 6). In addition, human haemoglobin peptides demonstrated $75 \%$ identity to turkey haemoglobin alpha and chicken haemoglobin alpha, 50\% identity to turkey haemoglobin beta and $66 \%$ identity to chicken haemoglobin beta proteins (Additional file 7). Therefore, we attempted to determine the incorporation of collagen alpha-1(VI) and haemoglobin in purified TAdV-3 using Western blot assays. As shown in Figure 4, anti-collagen alpha-1 (VI) serum detected collagen alpha-1 (VI) chain specific band in proteinase $\mathrm{K}$ untreated TAdV-3 (panel A, lane 1). Similar protein could be detected in proteinase $K$ treated purified TAdV-3 (panel A, lane 2). Antihaemoglobin serum detected haemoglobin specific band in proteinase $\mathrm{K}$ untreated TAdV-3 (panel B, lane 1). Similar protein band could be detected in proteinase $\mathrm{K}$ treated purified TAdV-3 (panel B, lane 2).

\section{Discussion}

Viruses exploit multiple host proteins for successful entry, establishment of infection, replication, and immune evasion. For a better understanding of the TAdV3-host interactions, we performed a comprehensive analysis of the protein content of TAdV-3 virions, using a LC-MS/MS based proteomic approach. To the best of our knowledge, incorporation of host proteins in adenovirus has not been reported so far.

The proteomic analysis of $\mathrm{CsCl}_{2}$ purified TAdV-3 identified a total of 13 virion proteins and 18 host proteins. Earlier, proteomic analysis has not reported the detection of host proteins in purified HAdV-5 virions $[15,16]$. It is possible that the observed host proteins identified by proteomic analysis of $\mathrm{CsCl}_{2}$ purified TAdV3 virions may not be actually incorporated in the purified virions but are loosely associated on the outside of the TAdV-3 virion capsids. Since proteinase K treatment has been traditionally used to remove any contaminating protein from the surface of enveloped viruses [33,35], we used protease treatment of non-enveloped TAdV-3 to remove the potential contaminating proteins. Several lines of evidence validate the approach and suggest that proteinase $\mathrm{K}$ treatment of TAdV-3 appears successful in removing contamination proteins. 1) Intact virions could be detected by TEM after proteinase $\mathrm{K}$ treatment of 


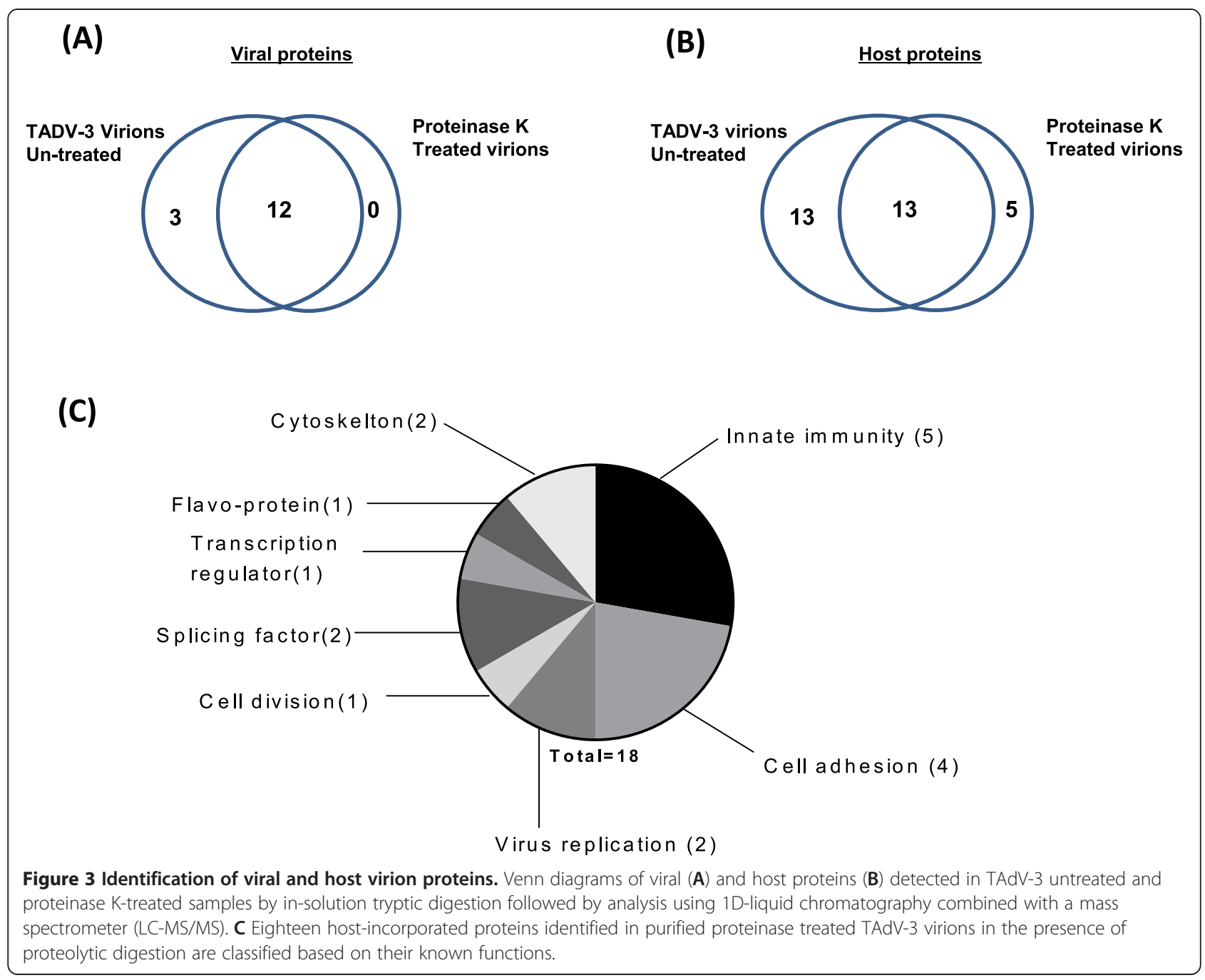

TAdV-3. 2) Western blot analysis of protease $\mathrm{K}$ treated TAdV-3 detected hexon protein but not fiber protein (protruding from the capsid). 3) The fiber and $22 \mathrm{~K}$ (non structural protein) could not be detected by MS analysis of proteinase $\mathrm{K}$ treated TAdV-3. 4) Only 18 of the 26 host proteins could be identified in proteinase $\mathrm{K}$ treated TAdV-3.

Interestingly, all major viral proteins were identified in proteinase $\mathrm{K}$ treated virions (Table 3 ) except viral pTP, possibly due to its low abundance and least mascot score values observed (Table 1). Overall sequence coverage observed for different viral peptides ranged from 2 to $70 \%$, with the majority between 10 and $35 \%$.

Earlier, sequence analysis of turkey adenovirus-3 identified a hypothetical protein ORF 4 (named TaVgp04) [7], which appears to be conserved in raptor adenovirus1 [36] and South polar skua adenovirus [37]. In contrast, a hypothetical hydrophobic protein was identified in frog adenovirus 1 [8], which shows no similarity to similar proteins identified in turkey adenovirus 3 [7] and raptor adenovirus 1 [36]. Our results suggest that an ORF4 of TAdV-3 encodes a structural protein TaVgp04, which is incorporated into virion capsid (Additional file 1). In addition, this is the first report to suggest the existence of TaVgp04 as a structural protein in siadenoviruses particularly of avian origin.

The proteomic analysis of proteinase $\mathrm{K}$ treated purified virions identified eleven cellular proteins incorporated in TAdV-3, which have been identified in other viruses (Table 4). In addition, proteomic analysis identified seven host proteins incorporated in TAdV-3 virions (Table 4), which have not been identified so far in any other virus. Interestingly, of the 18 detected host proteins, five of the proteins were only detected in proteinase $\mathrm{K}$ treated TAdV-3. It is possible that high abundance non-specific proteins might have masked the detection of these proteins in virions not treated with proteinase $\mathrm{K}$ that are truly virion associated, but present in low copy numbers. 
Table 4 Cellular proteins associated with purified TAdV-3 virions after proteinase $\mathrm{K}$ treatment

\begin{tabular}{|c|c|c|c|c|c|c|}
\hline \multirow[b]{2}{*}{ Protein name } & \multicolumn{6}{|l|}{ LC-MS/MS } \\
\hline & Mass $(\mathrm{kDa})^{\mathrm{a}}$ & $\begin{array}{l}\text { No. of } \\
\text { peptides }\end{array}$ & Mascot score $^{b}$ & $\begin{array}{l}\text { Sequence } \\
\text { coverage }(\%)^{c}\end{array}$ & Protein function & Reported in other viruses \\
\hline Protein PML isoform X6 & 48.4 & 8 & 141 & 10 & Innate immunity & - \\
\hline Collagen alpha-1 (VI) chain & 110 & 17 & 101 & 7 & Cell adhesion & - \\
\hline Vitronectin & 52.2 & 4 & 100 & 5 & Cell adhesion & $\mathrm{SIV}^{21}, \mathrm{KSHV}^{29}$ \\
\hline Hemoglobin subunit alpha -A like & 15.5 & 5 & 99 & 24 & Innate immunity & Corona $^{26}$, Influenza ${ }^{20}$ \\
\hline Collagen alpha-3 (VI) chain & 340 & 9 & 92 & 10 & Cell adhesion & - \\
\hline Collagen alpha-2 (VI) chain & 110 & 5 & 91 & 5 & Cell adhesion & Influenza ${ }^{20}$ \\
\hline Ferritin & 17.1 & 4 & 90 & 20 & Virus replication & $\mathrm{HCV}^{24}, \mathrm{sHEV}^{25}$ \\
\hline Elongation factor 1-alpha & 47.6 & 2 & 69 & 3 & Virus replication & HIV $^{13}$ \\
\hline Hemoglobin subunit-beta like & 16.3 & 8 & 66 & 27 & Innate immunity & $\mathrm{CSFV}^{45}$ \\
\hline Tyrosine protein phosphatase & 68 & 2 & 63 & 2 & Cell division & - \\
\hline Antimicrobial peptide THP-2 & 7.6 & 7 & 64 & 48 & Innate immunity & - \\
\hline Splicing factor U2AF & 28.7 & 5 & 60 & 9 & Splicing factor & $\mathrm{KSHV}^{29}$ \\
\hline Serine/arginine splicing factor $5 a$ & 30.1 & 1 & 43 & 3 & Splicing factor & Influenza ${ }^{20}$ \\
\hline TAR DNA binding protein 43 & 45.0 & 3 & 40 & 2 & Transcription & $\mathrm{HSV}^{14}, \mathrm{RSV}^{23}$ \\
\hline L-amino acid oxidase & 59.08 & 4 & 40 & 7 & Flavoprotein & - \\
\hline Gallinacin-2 & 7.6 & 4 & 39 & 26 & Innate immunity & - \\
\hline Tubulin alpha-1A & 50.9 & 4 & 32 & 4 & Cytoskeleton & HIV $^{13}$, Influenza ${ }^{11}$, ASFV $^{28}$ \\
\hline Actin & 42.2 & 3 & 32 & 5 & Cytoskeleton & HIV $^{13}$, Influenza ${ }^{11}$, ASFV $^{28}$ \\
\hline
\end{tabular}

Protein subsets identified by LC-MS/MS with/without protease treatment are shown in bold black.

${ }^{\text {aTheoritical molecular mass. }}$

${ }^{\mathrm{b}}$ A Mascot score $\geq 30$ is significant $(p<0.05)$.

'Sequence coverage is based on peptides with an unique sequence.

Though earlier reports have demonstrated the packaging of viral [38] or non viral RNAs [39] into purified adenovirus, recent reports have not described the detection of any cellular protein in purified Lizard adenovirus- 2 [40], a member of Atadenovirus genus and purified HAdV-5, a prototype of Mastadenovirus genus [15]. The absence of a cellular protein packaged in purified adenovirus virions could be due to variety of reasons.
As stated, the difference could be due to the technique used for analysis [15]. Alternatively, it is possible that packaging of the cellular proteins may be dependent on the type of adenovirus (TAdV-3, a prototype of Siadenovirus genus) and origin of cells used for virus cultivation [15].

The host proteins packaged inTAdV-3 are known to play important roles in enhancing the cell-to-cell spread
(A)

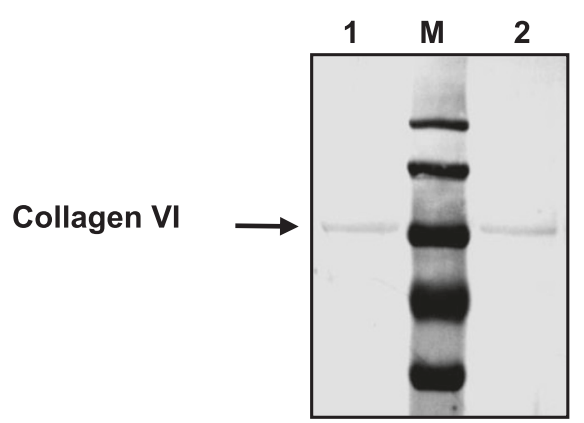

(B)

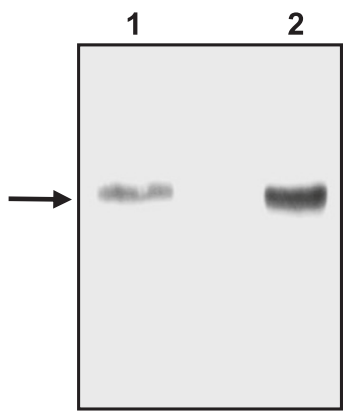

Figure 4 Western blot analysis of host proteins in TAdV-3. Proteins from the proteinase K untreated purified TAdV-3 virions (panels $\mathbf{A}$, $\mathbf{B}$, lane 1) and proteinase $\mathrm{K}(20 \mu \mathrm{g}$ incubated in $1 \mathrm{~mL}$ of MNT buffer) treated purified TAdV-3 virions (panels $\mathbf{A}, \mathbf{B}$, lane 2) were separated by 10-15\% SDSPAGE, transferred to nitrocellulose and analyzed by Western blot using anti-collagen alpha-1(VI) chain serum (panel $\mathbf{A})$ and anti-haemoglobin serum (panel B). Molecular weight markers (Lane M). 
of virus, transcription and virus replication (Table 4, Figure 3). For example, extracellular matrix (collagen) has been shown to increase infectious Sindbis virus titers from BHK cells by enhancing post-infection cell survival [41]. In another study, rotavirus-induced PI3K activation resulted in prolonged adherence of infected cells to collagen and increased virus production [42]. Similarly, extracellular matrix vitronectin has been reported to enhance the growth of human adenovirus19 (HAdV-19) [43].

However, the incorporation of antiviral host defense factors including, protein PML, haemoglobin and antimicrobial peptide (THP-2) into TAdV-3 virions is particularly intriguing. All of these host defence factors have been implicated in establishing antiviral environments. Recent studies have implicated PML in maintaining host antiviral defence and revealed different strategies developed by viruses to disrupt PML nuclear bodies [44-46]. In addition, protein PML has been shown to be important for the inhibition of adenovirus replication [47]. Similarly, avian antimicrobial peptide THP-2, a member of beta-defensin family is effector of the innate defence system and play key functions during host defence by generating vigorous cytokine response $[48,49]$. On the other hand, a novel role of haemoglobin in innate immunity has been recently reported for classical swine fever virus (CSFV) [50] as silencing of haemoglobin expression using siRNA promoted CSFV growth and replication, whereas overexpression of haemoglobin antagonized CSFV replication and growth by triggering IFN signalling [50].

Although TAdV-3 grows efficiently in spleen of infected turkey, virus grows poorly in primary or established cell lines. It is tempting to speculate that integration of certain established antiviral host restriction factors into viral particles may play a role in determining TAdV-3 replication "in vitro". Additional studies need to be performed in order to investigate whether these proteins are functionally required for virus entry, replication and pathogenesis. Future availability of reagents and a reliable cell culture system to grow TAdV-3 should make it possible to determine the role of individual host restriction factor in TAdV-3 replication.

\section{Additional files}

Additional file 1: Novel viral protein TaV3gp04. Sequence showing peptides detected in LC-MS/MS.

Additional file 2: Amino acid sequence of protein PML. Sequence showing peptides detected in LC-MS/MS.

Additional file 3: Amino acid sequence of collagen alpha-1(VI) chain. Sequence showing peptides detected in LC-MS/MS.

Additional file 4: Amino acid sequence of haemoglobin subunit alpha-A-like. Sequence showing peptides detected in LC-MS/MS.
Additional file 5: Amino acid sequence of haemoglobin subunit beta-like. Sequence showing peptides detected in LC-MS/MS.

Additional file 6: Amino acid sequence similarity of collagen alpha-1(VI) peptides. i) Human (accession number NP_001839) ii) turkey (accession number XP_003207392.1) iii) chicken (accession number CAA45788.1) peptide residues. Numbers to the left are the peptide position in coding sequence of the protein. Matched peptides shown in color.

Additional file 7: Amino acid sequence similarity of Haemoglobin peptides. i) Human haemoglobin (accession number NP_000549.1) ii) Chicken haemoglobin alpha (accession number NP_001004376.1) iii) Chicken haemoglobin beta (NP_990820.1) iv) Turkey haemoglobin alpha (accession number XP_003210796.1) V) Turkey haemoglobin beta (accession number XP_003203315.1) peptide residues. Numbers to the left are the peptide position in coding sequence. Matched peptides shown in colour.

\section{Competing interests}

The authors declare that they have no competing interests.

\section{Authors' contributions}

Conceived and designed the experiments: PK, SKT. Performed the experiments; PK, JV, AG, LEA. Analyzed the data; PK, JV, SKT; AG. Wrote the manuscript: PK, LEA, SKT. All authors read and approved the final manuscript.

\section{Acknowledgements}

Authors thank other members of Tikoo's laboratory for helpful suggestions. Published as VIDO-InterVac article \# 725. The work was supported by grants from Saskatchewan Agriculture Development Fund, Alberta livestock and Meat Agency, Saskatchewan Chicken Industry Development Fund, Canadian Poultry Research Council and Agriculture and Agri-Food Canada.

Received: 7 January 2015 Accepted: 10 June 2015

Published online: 09 July 2015

\section{References}

1. Beach NM, Duncan RB, Larsen CT, Meng XJ, Sriranganathan N, Pierson FW (2009) Comparison of 12 turkey hemotthagic enteritis virus isolates allows prediction of genetic factors affecting virulence. J Gen Virol 90:1978-1985

2. Mayo MA (2002) ICTV at Paris ICV: Results of the plenary session and the Binomial Ballot. Arch Virol 147:2254-2260

3. McFerran JB, Smyth JA (2000) Avian adenoviruses. Rev Sci Tech 19:589-601

4. van den Hurk JV, van Drunen Littel-van den Hurk S (1988) Characterization of group II avian adenoviruses with a panel of monoclonal antibodies. Can J Vet Res 52:458-467

5. Barbour EK, Poss PE, Brinton MK, Johnson JB, Nabbut NH (1993) Evaluation of cell culture propagated and in vivo propagated hemorrhagic enteritis vaccines in turkeys. Vet Immunol Immunopathol 35:375-383

6. Shah JD, Scharber SK, Cardona CJ (2013) Development and application of quantitative real-time PCR for the rapid detection of hemorrhagic enteritis virus in tissue samples. Avian Dis 57:300-302

7. Pitcovski J, Mualem M, Rei-Koren Z, Krispel S, Shmueli E, Peretz Y, Gutter B, Gallili GE, Michael A, Goldberg D (1998) The complete DNA sequence and genome organization of the avian adenovirus, hemorrhagic enteritis virus. Virology 249:307-315

8. Davison AJ, Benko M, Harrach B (2003) Genetic content and evolution of adenoviruses. J Gen Virol 84:2895-2908

9. van den Hurk JV (1992) Characterization of the structural proteins of hemorrhagic enteritis virus. Arch Virol 126:195-213

10. Chertova E, Chertov O, Coren LV, Roser JD, Trubey CM, Bess JW Jr, Sowder RC 2nd, Barsov E, Hood BL, Fisher RJ, Nagashima K, Cnrads TP, Veenstra TD, Lifson JD, Ott DE (2006) Proteomic and biochemical analysis of purified human immunodeficiency virus type 1 produced from infected monocyte-derived macrophages. J Virol 80:9039-9052

11. Kummer S, Flottmann M, Schwanhausser B, Sieben C, Veit M, Selbach M Klipp E, Herrmann A (2014) Alteration of protein levels during influenza virus H1N1 infection in host cells: a proteomic survey of host and virus reveals differential dynamics. PLoS One 9:e94257 
12. Mendes M, Perez-Hernandez D, Vazquez J, Coelho AV, Cunha C (2013) Proteomic changes in HEK-293 cells induced by hepatitis delta virus replication. J Proteomics 89:4-38

13. Saphire AC, Gallay PA, Bark SJ (2006) Proteomic analysis of human immunodeficiency virus using liquid chromatography/tandem mass spectrometry effectively distinguishes specific incorporated host proteins. J Proteome Res 5:530-538

14. Taylor TJ, Knipe DM (2004) Proteomics of herpes simplex virus replication compartments: association of cellular DNA replication, repair, recombination, and chromatin remodeling proteins with ICP8. J Virol 78:5856-5866

15. Alqahtani A, Heesom K, Bramson J, Curiel D, Ugai H, Matthews D (2014) Analysis of purified wild type and mutant adenovirus particles by SILAC based quantitative proteomics. J Gen Virol 95:2504-2511

16. Chelius D, Huhmer AF, Shieh CH, Lehmberg E, Traina JA, Slattery TK, Pungor E Jr (2002) Analysis of the adenovirus type 5 proteome by liquid chromatography and tandem mass spectrometry methods. J Proteome Res 1:501-513

17. Di Domenico F, De Marco F, Perluigi M (2013) Proteomics strategies to analyze HPV-transformed cells: relevance to cervical cancer. Expert Rev Proteomics 10:461-472

18. Lind SB, Artemenko KA, Pettersson U (2014) Proteome analysis of adenovirus using mass spectrometry. Methods Mol Biol 1089:25-44

19. Cantin R, Methot S, Tremblay MJ (2005) Plunder and stowaways: incorporation of cellular proteins by enveloped viruses. J Virol 79:6577-6587

20. Shaw ML, Stone KL, Colangelo CM, Gulcicek EE, Palese P (2008) Cellular proteins in influenza virus particles. PLoS Pathog 4:1000085

21. Wiederin JL, Donahoe RM, Anderson JR, Yu F, Fox HS, Gendelman HE, Ciborowski PS (2010) Plasma proteomic analysis of simian immunodeficiency virus infection of rhesus macaques. J Proteome Res 9:4721-4731

22. Munday DC, Emmott E, Surtees R, Lardeau CH, Wu W, Duprex WP, Dove BK, Barr JN, Hiscox JA (2010) Quantitative proteomic analysis of A549 cells infected with human respiratory syncytial virus. Mol Cell Proteomics 9:2438-2459

23. Mancone C, Montaldo C, Santangelo L, Di Giacomo C, Costa V, Amicone L, Ippolito G, Pucillo LP, Alonzi T, Tripodi M (2012) Ferritin heavy chain is the host factor responsible for HCV-induced inhibition of apoB-100 production and is required for efficient viral infection. J Proteome Res 11:2786-2797

24. Lee G, Han D, Song JY, Kim JH, Yoon S (2011) Proteomic analysis of swine hepatitis $\mathrm{E}$ virus (sHEV)-infected livers reveals upregulation of apolipoprotein and down- regulation of ferritin heavy chain. FEMS Immunol Med Microbiol 61:359-363

25. Neuman BW, Joseph JS, Saikatendu KS, Serrano P, Chatterjee A, Johnson MA, Liao L, Klaus JP, Yates JR 3rd, Wuthrich K, Stevens RC, Buchmeier MJ, Kuhn P (2008) Proteomics analysis unravels the functional repertoire of coronavirus nonstructural protein 3. J Virol 82:5279-5294

26. Coombs KM, Berard A, Xu W, Krokhin O, Meng X, Cortens JP, Kobasa D, Wilkins J, Brown EG (2010) Quantitative proteomic analyses of influenza virus-infected cultured human lung cells. J Virol 84:10888-10906

27. Sanchez-Quiles V, Mora MI, Segura V, Greco A, Epstein AL, Foschini MG, Dayon L, Sanchez JC, Prieto J, Corrales FJ, Santamaria E (2011) HSV-1 Cgal + infection promotes quaking RNA binding protein production andinduces nuclear-cytoplasmic shuttling of quaking I-5 isoform in human hepatoma cells. Mol Cell Proteomics 10:5

28. Esteve A, Marques MI, Costa JV (1986) Two-dimensional analysis of African swine fever virus proteins and proteins induced in infected cells. Virology 152:192-206

29. Si H, Verma SC, Robertson ES (2006) Proteomic analysis of the Kaposi's sarcoma-associated herpesvirus terminal repeat element binding proteins. J Virol 80:9017-9030

30. Liu HC, Soderblom EJ, Goshe MB (2006) A mass spectrometry-based proteomic approach to study Marek's Disease Virus gene expression. J Virol Methods 135:66-75

31. Renesto P, Abergel C, Decloquement P, Moinier D, Azza S, Ogata H, Fourquet P, Gorvel JP, Claverie JM (2006) Mimivirus giant particles incorporate a large fraction of anonymous and unique gene products. J Virol 80:11678-11685

32. van den Hurk JV (1990) Propagation of group II avian adenoviruses in turkey and chicken leukocytes. Avian Dis 34:12-25
33. Kramer T, Greco TM, Enquist LW, Cristea IM (2011) Proteomic characterization of pseudorabies virus extracellular virions. J Virol 85:6427-6441

34. Richardson KC, Jarett L, Finke EH (1960) Embedding in epoxy resins for ultrathin sectioning in electron microscopy. Stain Technol 35:313-323

35. Lete C, Palmeira L, Leroy B, Mast J, Machiels B, Wattiez R, Vanderplasschen A, Gillet $L$ (2012) Proteomic characterization of bovine herpesvirus 4 extracellular virions. J Virol 86:11567-11580

36. Kovacs ER, Benko M (2011) Complete sequence of raptor adenovirus 1 confirms the characteristic genome organization of siadenovirus. Infect Genet Evol 11:1058-1065

37. Park YM, Kim J-H, Gu SH, Lee SY, Lee M-G, Kang YK, Kang S-H, Kim HJ, Song J-W (2012) Full genome analysis of a novel adenovirus from the south ploar skua (Catharacta maccormicki) in Antarctica. Virology 422:144-150

38. Xing L, Tikoo SK (2004) Viral RNAs detected in virions of porcine adenovirus type 3. Virology 321:372-382

39. Chung SW, Arnott JA, Yang Y, Wong PM (2003) Presence of prepackaged mRNA in virions of DNA adenovirus. J Biol Chem 278:50635-50640

40. Penzes JJ, Menendez-Conejero R, Condezo GN, Ball I, Papp T, Doszpoly A, Paradela A, Perez-Berna AJ, Lopez-Sanz M, Nguyen TH, van Raiji MJ, Marcschang RE, Harrach B, Benko M, Martin CS (2014) Molecular characterization of a lizard adenoivirus reveals the first atadenoivirus with two fiber genes and the first adenovirus with either one short or three long fibers per penton. J Virol 88:11304-11314

41. Thach DC, Stenger DA (2003) Effects of collagen matrix on Sindbis virus infection of BHK cells. J Virol Methods 109:153-160

42. Halasz P, Holloway G, Turner SJ, Coulson BS (2008) Rotavirus replication in intestinal cells differentially regulates integrin expression by a phosphatidylinositol 3-kinase-dependent pathway, resulting in increased cell adhesion and virus yield. J Virol 82:148-160

43. Xiao J, Natarajan K, Rajala MS, Astley RA, Ramadan RT, Chodosh J (2005) Vitronectin: a possible determinant of adenovirus type 19 tropism for human corneal epithelium. Am J Ophthalmol 140:363-369

44. Bonilla W, Pinschewer DD, Klenerman P, Rousson V, Gaboli M, Pandolfi PP, Zinkernagel RM, Salvato MS, Hengartner H (2002) Effects of promyelocytic leukemia protein on virus-host balance. J Virol 76:3810-3818

45. Blondel D, Regad T, Poisson N, Pavie B, Harper F, Pandolfi PP, De Thé H, Chelbi-Alix MK (2002) Rabies virus $P$ and small $P$ products interact directly with PML and reorganize PML nuclear bodies. Oncogene 21:7957-7970

46. Iki S, Yokota S, Okabayashi T, Yokosawa N, Nagata K, Fujii N (2005) Serum-dependent expression of promyelocytic leukemia protein suppresses propagation of influenza virus. Virology 343:106-115

47. Ullman AJ, Reich NC, Hearing P (2007) Adenovirus E4 ORF3 protein inhibits the interferon-mediated antiviral response. J Virol 81:4744-4752

48. Boniotto M, Jordan WJ, Eskdale J, Tossi A, Antcheva N, Crovella S, Connell ND, Gallagher G (2006) Human beta-defensin 2 induces a vigorous cytokine response in peripheral blood mononuclear cells. Antimicrob Agents Chemother 50:1433-1441

49. Evans EW, Beach FG, Moore KM, Jackwood MW, Glisson JR, Harmon BG (1995) Antimicrobial activity of chicken and turkey heterophil peptides CHP1, CHP2, THP1, and THP3. Vet Microbiol 47:295-303

50. Li D, Dong H, Li S, Munir M, Chen J, Luo Y, Sun Y, Liu L, Qiu HJ (2013) Hemoglobin subunit beta interacts with the capsid protein and antagonizes the growth of classical swine fever virus. J Virol 87:5707-5717

\section{Submit your next manuscript to BioMed Central and take full advantage of:}

- Convenient online submission

- Thorough peer review

- No space constraints or color figure charges

- Immediate publication on acceptance

- Inclusion in PubMed, CAS, Scopus and Google Scholar

- Research which is freely available for redistribution 